\title{
Gas Emissions and Metallic Contents of Commonly Used Fuelwood in Nigeria
}

\author{
O. N. Omaka ${ }^{1}$, F. I. Nwabue ${ }^{2}$, E. J. Itumoh ${ }^{2} \&$ G. N. Okeke ${ }^{2}$ \\ ${ }^{1}$ Department of Chemistry/Biochemistry/Molecular Biology, Federal University Ndufu, Alike Ikwo, Ebonyi \\ State, Nigeria \\ ${ }^{2}$ Department of Industrial Chemistry, Ebonyi State University Abakaliki, Ebonyi State, Nigeria \\ Correspondence: F. I. Nwabue, Department of Industrial Chemistry, Ebonyi State University, PO Box 347 \\ Abakaliki, Ebonyi State, Nigeria. Tel: 234-803-705-9082. Email: energymixnig@yahoo.com
}

Received: December 27, 2012 Accepted: March 19, 2013 Online Published: June 26, 2013

doi:10.5539/ep.v2n3p100 URL: http://dx.doi.org/10.5539/ep.v2n3p100

\begin{abstract}
Gas emissions levels of $\mathrm{NO}, \mathrm{NO}_{2}, \mathrm{SO}_{2}, \mathrm{CO}$, and $\mathrm{CO}_{2}$ from commonly used domestic fuel wood were investigated using Carbolite Muffler Furnace equipped with gas probes. Results after analysis showed gas levels in ppm in the range 0.1-29.6 for $\mathrm{NO}, 0.1-10.0$ for $\mathrm{NO}_{2}, 1.2-21.0$ for $\mathrm{SO}_{2}, 0-0.2$ for $\mathrm{CO}$, and $90-560$ for $\mathrm{CO}_{2}$. Analysis of the resulting wood ash showed metal levels in $\mathrm{gkg}^{-1}$ in the range 2.16-10.37 for $\mathrm{Ca}, 0.29-1.58$ for $\mathrm{Mg}, 1.04-3.53$ for $\mathrm{Zn}$, and $0.24-0.84$ for Al. Compared to the recommended short term exposure limits, the observed gas levels of $\mathrm{SO}_{2}$ and $\mathrm{NO}_{2}$ indicate environmentally unfriendly nature of some of the commonly used domestic fuel wood and the possible risk of respiratory, pulmonary and carcinogenic diseases that could be associated with their regular usage. The wood ash composition suggests it could serve a friendly utilization as soil additive for agricultural purposes for soils whose compositions show deficiency of these metals.
\end{abstract}

Keywords: gas emissions, fuel wood, metallic content, wood ash

\section{Introduction}

Many rural communities in developing countries still depend on a variety of forest wood resources for their indoor and outdoor domestic cooking, drying of harvested products and house warming among other uses (Robinson, 2011; Njiong \& Johannes, 2011; Tanimowo, 2000). Gas and particulate matter emissions from domestic fuel wood usage are increasingly becoming a great source of concern because of high incidence of respiratory, pulmonary and carcinogenic diseases that have been associated with their regular usage (Environment Australia, 2002; Smith, 2002; Enwereji \& Ezeama, 2009; Guggisberg et al., 2003; Diaz et al., 2007; Riojas-Rodriguez et al., 2001). A popular but unsubstantiated belief in most developing countries is that domestic cooking with fuel wood is faster and gives a better taste of the food. In local communities, wood ash has found a number of applications as a source of potash, liming and tannin extracting agent in poultry feeds, in water treatment, as degreaser or scouring powder and for traditional bone-setting therapy (Misra et al., 1993; Pitman, 2011; Suruchi \& Pankaj, 2011). So far carbon emission levels and those of other pollutants resulting from the use of biomass and inefficient biomass stoves, including the utilization of the resulting ash, in developing countries have not been fully studied (Tanimowo, 2000; Enwereji \& Ezeama, 2009; Pérez-Padilla et al., 1999).

The present study was carried out to estimate emission levels of $\mathrm{NO}, \mathrm{NO}_{2}, \mathrm{SO}_{2}, \mathrm{CO}$, and $\mathrm{CO}_{2}$ in some commonly used fuel wood in Nigeria and analyze the essential metal content of the resulting wood ash which is being utilized in agriculture and domestic products preparations by rural community dwellers.

\section{Materials and Method}

\subsection{Reagents}

All reagents used were of analytical grade purity and were used without further purification except were otherwise stated.

Distilled deionized water was used all through the experiments. 
EDTA, disodium salt (BDH Poole, England) was prepared as $0.1 \mathrm{M}$ solution and standardized using $0.1 \mathrm{M}$ $\mathrm{ZnSO}_{4}$ following procedure described elsewhere (Mendham et al., 2004). Dilution was done as required.

Ammonia-ammonium chloride buffer $(\mathrm{pH}=10)$ was prepared and adjusted with dilute acid or ammonium hydroxide.

\subsection{Apparatus}

Muffler Furnace Carbolite RHF 1600 fitted with probes of single gas analyzers; 92, 93, 94, 96, and 97 located at Sheda Science and Technology Complex, Sheda, Abuja, Nigeria were used for ashing and for the analysis of NO, $\mathrm{NO}_{2}, \mathrm{SO}_{2}, \mathrm{CO}_{2}$, and $\mathrm{CO}$ levels from burning wood samples respectively.

Electric drying oven, DHG 9023A, was used for drying the wood samples while pH meter, C175 Hanna Instruments Italy, was used for $\mathrm{pH}$ measurements.

\subsection{Sample Collection}

Commonly used fuel wood which are forest Down Wood Materials (DWM) of the following plants; orange (Citrus spp.), cassava (Manihot spp.), gmelina (Gmelina aborea), mango (Mangiferia indica), Indian bamboo (Dracaena sandaeriana), oil bean (Recinus communis), rowam (Sorbus acuparia), pear (Pyrus communis), guava (Psdium guajava L.) and iroko (Chlorophora excelsa), stacked for domestic use in different homes within 200 meters radius in communities in Afikpo North/South, Ivo, Abakaliki, Izzi, Ezza North, and Ohaukwu Local Government Areas of Ebonyi State Nigeria, were sampled at random for the Fine Woody Debris (FWD) of medium size (0.25-1.0 inch diameter). Six log samples of each plant which were of sound, freshly-fallen and intact quality with absence of decay were sampled, two each from top, middle and bottom of a pile. The six samples were reduced to small sizes and pulled together by type as composite samples for ease of transportation to the laboratory for analysis.

\subsection{Sample Preparation and Analysis}

\subsubsection{Analysis of Gas Emissions}

The composite wood samples were reduced to about $4 \mathrm{~mm}$ size using wood saw. The samples were oven-dried for 5 hours at $95^{\circ} \mathrm{C}$. Weighed dry samples were placed in porcelain containers, labeled correctly and transferred to the furnace. The temperature of the furnace was set at $350{ }^{\circ} \mathrm{C}$ and switched on with the meters of the various probe gas analyzers connected to the exhaust chimney of the furnace (Figures 1,2 and 3). The samples were allowed to burn completely in the furnace and the gases produced were recorded in parts per million (ppm) by the probe meters of the analyzers which have the ability to draw in the gas produced. The process was repeated for consistent results making sure the furnace was flushed with nitrogen to remove any residual gases each time. The analysis method using the Muffler Furnace Carbolite RHF 1600 with the gas analyzer probes is reliable with about $95 \%$ confidence level.

\subsubsection{Analysis of Ash Samples}

The resulting wood ash from the analysis of gas emissions was analyzed for metallic contents. $\mathrm{Mg}, \mathrm{Ca}, \mathrm{Zn}$, and $\mathrm{Al}$ found present were determined by EDTA complexometric titration following standard procedure (Mendham et al., 2004).

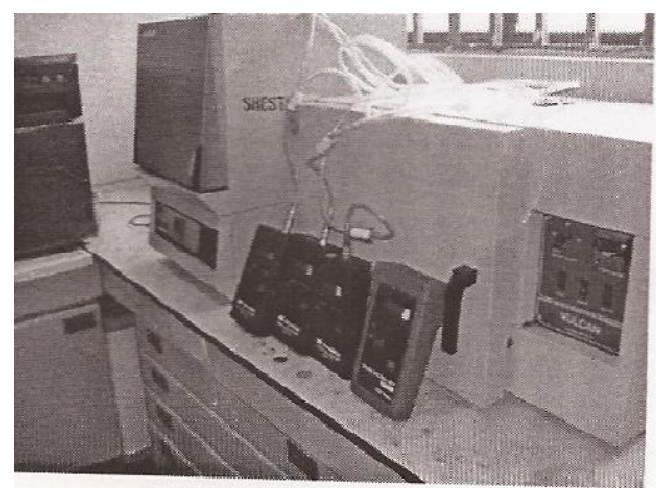

Figure 1. Muffler Furnace Carbolite RHF 1600 fitted with probes of single gas analyzers (Furnace is to the left of gas analyzers) 


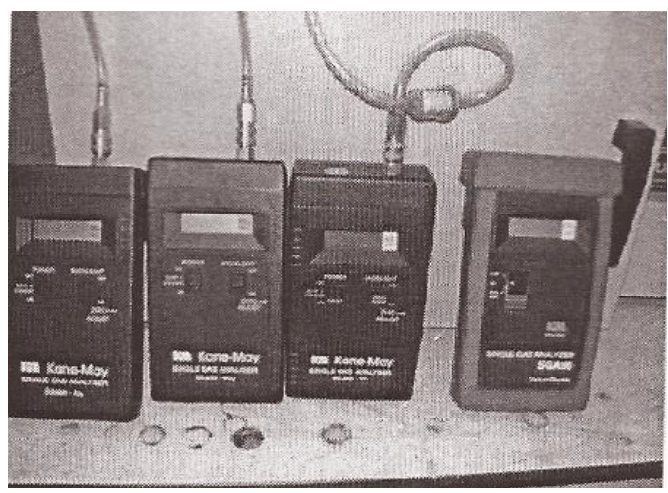

Figure 2. Single gas analyzers

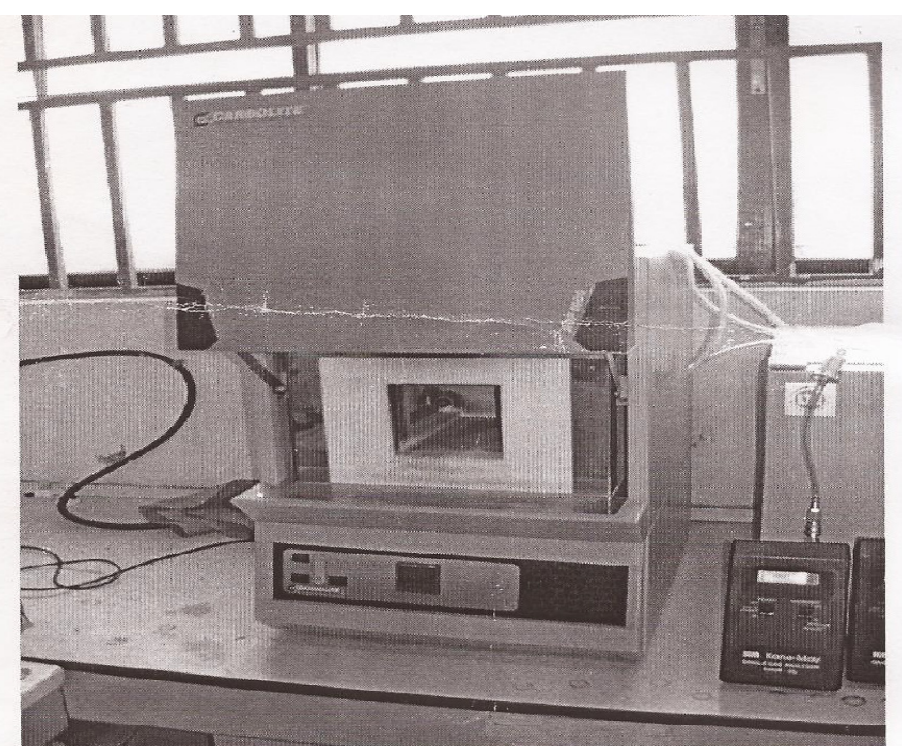

Figure 3. Muffler Furnace Carbolite RHF 1600 in open possition (a single gas analyzer is to the right)

\section{Results and Discussion}

Table 1 shows the results obtained for the emission of $\mathrm{CO}_{2}, \mathrm{CO}, \mathrm{NO}, \mathrm{NO}_{2}$, and $\mathrm{SO}_{2}$ from the combustion of fuel wood samples collected from different communities in seven Local Government areas of Ebonyi State Nigeria and which were compared with the values for the recommended maximum emission limits for these gases in Michigan State USA (MDLRA, 1974). The particulate matter emission was not analyzed because of absence of the analyzer probe. Of all the fuel wood resources analyzed cassava appears to have the highest carbon footprint while pear and mango have the lowest. The low emission levels of CO generally observed from the combustion of the fuel wood samples studied indicate efficient combustion of the samples in the furnace which may not be the case when local biomass stoves are used under wet conditions of these forest resources. Cassava, just like orange, shows low levels of $\mathrm{NO}$ and $\mathrm{NO}_{2}$ compared with the other wood resources even though it emitted higher levels of $\mathrm{SO}_{2}$ than the maximum allowed limit and therefore the use of cassava as a fuel wood resource constitutes a serious hazard to health. Most of the observed fuel wood emissions of $\mathrm{NO}$ and $\mathrm{NO}_{2}$ did not exceed the maximum allowed limits except for oil bean tree which gave a high emission level of $\mathrm{NO}_{2}$. However, $\mathrm{NO}_{2}$ emissions from these wood resources exceeded the short-term exposure limits except for Gmelina and Indian bamboo as shown in Table 1 and, for this reason, the use of these wood resources for cooking in a kitchen or enclosed environment is not a healthy practice. As observed by Chen et al. (2008), there is a significant adverse health effect of exposure to $\mathrm{SO}_{2}$ and $\mathrm{NO}_{2}$ on a daily basis as these gaseous pollutants can independently contribute to increase in daily mortality. Apart from the incidence of toxicity to humans, animals and plants, high levels of gas emissions from fuel wood utilization contribute to greenhouse gases with their attendant effects of global warming, ozone layer depletion, the phenomenon of acid rain, deforestation and desertification (Robinson, 2011; Chen et al., 2008; Najjar, 2011; Jayaratne \& Verma, 2001; Moreira et al., 2008). The levels of gas 
emissions from fuel wood could also contribute to various birth complications among women (Boy et al., 2002). Table 1 also shows a significant variation in $\mathrm{NO}, \mathrm{NO}_{2}$ and $\mathrm{SO}_{2}$ emission levels for each of the respective wood samples when compared for different locations. This is evident in the results for Gmelina, Mango and Cassava fuel wood samples. The observed emission levels for these gases are higher for wood samples from Abakaliki and Afikpo North, which are urban cities, than for the samples from Ivo and Ezza North which are rural communities. The observed higher emissions may therefore be attributed to anthropogenic factors related to soil contamination with N- and S- containing compounds in the urban cities studied. Invariably, these compounds or their derivatives are picked up as part of plant nutrients from the soil (Singh, 2001).

Table 1. Gas emission levels (in ppm) found in the fuel wood samples (mean of triplicate analysis \pm SD)

\begin{tabular}{|c|c|c|c|c|c|}
\hline Sample/Source & $\mathrm{CO}_{2}$ & $\mathrm{CO}$ & NO & $\mathrm{NO}_{2}$ & $\mathrm{SO}_{2}$ \\
\hline \multicolumn{6}{|c|}{ Afikpo North } \\
\hline Gmelina & $260 \pm 0.001$ & $0.1 \pm 0.013$ & $0.5 \pm 0.012$ & $1.1 \pm 0.002$ & $1.2 \pm 0.018$ \\
\hline Cassava & $360 \pm 0.011$ & $0.1 \pm 0.005$ & - & - & $21.0 \pm 0.015$ \\
\hline Indian bamboo & $120 \pm 0.003$ & - & $0.4 \pm 0.010$ & $0.4 \pm 0.006$ & $1.4 \pm 0.007$ \\
\hline \multicolumn{6}{|c|}{ Ivo } \\
\hline Gmelina & $115 \pm 0.007$ & - & $0.2 \pm 0.011$ & $0.2 \pm 0.006$ & $0.8 \pm 0.010$ \\
\hline Mango & $95 \pm 0.002$ & $0.2 \pm 0.005$ & $0.1 \pm 0.002$ & $2.2 \pm 0.001$ & $0.6 \pm 0.006$ \\
\hline Iroko & $110 \pm 0.001$ & - & $0.8 \pm 0.010$ & $3.2 \pm 0.003$ & - \\
\hline \multicolumn{6}{|c|}{ Abakaliki } \\
\hline Mango & $285 \pm 0.018$ & - & $1.8 \pm 0.015$ & $2.4 \pm 0.001$ & $1.2 \pm 0.013$ \\
\hline Cassava & $450 \pm 0.005$ & - & - & $1.0 \pm 0.003$ & $20.1 \pm 0.010$ \\
\hline Oil bean & $290 \pm 0.005$ & - & - & $6.1 \pm 0.005$ & $2.1 \pm 0.002$ \\
\hline Pear & $90 \pm 0.001$ & - & $2.1 \pm 0.011$ & $4.0 \pm 0.015$ & $1.8 \pm 0.007$ \\
\hline \multicolumn{6}{|c|}{ Ohaukwu } \\
\hline Guava & $102 \pm 0.005$ & - & - & $2.1 \pm 0.003$ & $4.0 \pm 0.013$ \\
\hline \multicolumn{6}{|c|}{ Afikpo South } \\
\hline Orange & $250 \pm 0.002$ & - & - & - & $0.7 \pm 0.006$ \\
\hline \multicolumn{6}{|c|}{ Izzi } \\
\hline Rowam & $150 \pm 0.010$ & $0.2 \pm 0.002$ & $0.4 \pm 0.018$ & - & $1.5 \pm 0.007$ \\
\hline \multicolumn{6}{|c|}{ Ezza North } \\
\hline Cassava & $195 \pm 0.015$ & - & $0.5 \pm 0.003$ & $1.5 \pm 0.006$ & $14.2 \pm 0.001$ \\
\hline *STEL & - & - & - & 1.0 & 5.0 \\
\hline *MAC & - & 50.0 & 25.0 & 5.0 & 5.0 \\
\hline
\end{tabular}

*STEL $=$ Short-Term Exposure Limit, ${ }^{*}$ MAC $=$ Maximum Allowed Limits. *Source: (MDLRA, 1974).

Table 2 shows the results of the concentrations of the essential metals found in the ash samples of fuel wood under study. The results were compared with minimum and maximum limit values for minor elements and nutrients in the Nordic countries according to the Sweden Recommendations Draft (SRD) 2007 for forestry applications (Hugland and Expert Group, 2008). Many of the developing countries are known for their use of wood ash and household wastes for agricultural purposes (Pasquini, 2006). From the results of our analyses, metals found in the wood ash samples were all below the recommended limit values for forestry application and therefore can be utilized as additives for agricultural purposes on soils which are deficient on these minerals. However, for cassava and gmelina that have high concentrations of $\mathrm{Zn}$ closer to the limits, caution is required in their use. The general trends for major elements in wood ash obtained from component parts of plants as reviewed by Pitman (2011) is in the order; foliage branch $>$ stem bark $>$ stem wood. The observed percentage levels of $\mathrm{Ca}, \mathrm{Mg}, \mathrm{Zn}$, and $\mathrm{Al}$ in the analyzed wood ash samples under study are; 0.2-1.0, 0.03-0.25, 0.1-0.35, 
and 0.01-0.09 respectively which are consistent with the general trends for these metals in stem bark and stem wood. Persistent use of wood ash as agricultural additive for a long time could result to high metal contents of the receiving soils, which could also lead to ground and surface water pollution through metal leaching (Singh, 2001). Low level metal intake from food grown on metal contaminated soils has been shown to lead to bioaccumulative toxicity, and there is so far no effective mechanism found for elimination of metals from the body (Clark, 1992). Table 2 also shows variation in metal concentration levels in ash samples of a particular plant from different locations. Soil is one of the repositories for anthropogenic wastes, and a major pathway of soil contamination is through atmospheric deposition of trace metals from point sources such as metaliferrous mining, quarrying and industrial activities (Singh, 2001). The largest ore bodies in the Benue Trough are distributed in the Abakaliki and Ishiagu districts (lower Benue) on the main axis of a major anticlinal structure known as the Abakaliki anticlinorium (Akande \& Erdtmann, 1995). The communities under study are within the two districts and mining and quarrying of pyroclastics, limestone, sphererite and other mineral ores have been carried out mainly in Ivo, Ezza North and Abakaliki communities for the past two decades. However soil composition mapping of these communities have not been carried out and hence it will be difficult to relate soil composition with metal uptake by the plants studied. Moreover, it has been suggested that uptake of metals by plants is dependent on chemical form of the metals in the contaminated soil (Gundermann et al., 1995). Generally, the observed higher concentration levels of $\mathrm{Ca}, \mathrm{Mg}, \mathrm{Zn}$, and $\mathrm{Al}$ in the ash samples of Cassava, Gmelina and Mango collected from Abakaliki, Ezza North and Ivo can be attributed to the impact of mining and quarrying activities in these communities over these years.

Table 2. Concentration of essential metals (in $\mathrm{gkg}^{-1}$ ) found in fuelwood ash samples (mean of triplicate analysis $\pm \mathrm{SD})$

\begin{tabular}{|c|c|c|c|c|}
\hline Wood ash Sample/Source & $\mathrm{Ca}^{2+}$ & $\mathrm{Mg}^{2+}$ & $\mathrm{Zn}^{2+}$ & $\mathbf{A l}^{3+}$ \\
\hline \multicolumn{5}{|c|}{ Afikpo North } \\
\hline Gmelina & $3.08 \pm 0.001$ & $1.54 \pm 0.013$ & - & $0.24 \pm 0.018$ \\
\hline Cassava & $3.93 \pm 0.007$ & $1.74 \pm 0.005$ & $1.19 \pm 0.015$ & $0.86 \pm 0.015$ \\
\hline Indian bamboo & $5.63 \pm 0.018$ & $1.23 \pm 0.001$ & $1.04 \pm 0.002$ & $0.14 \pm 0.001$ \\
\hline \multicolumn{5}{|c|}{ Ivo } \\
\hline Gmelina & $6.49 \pm 0.003$ & $0.29 \pm 0.001$ & $3.16 \pm 0.010$ & $0.72 \pm 0.005$ \\
\hline Mango & $5.51 \pm 0.006$ & $1.31 \pm 0.001$ & - & $0.69 \pm 0.002$ \\
\hline Iroko & $6.46 \pm 0.001$ & $0.95 \pm 0.007$ & - & - \\
\hline \multicolumn{5}{|c|}{ Abakaliki } \\
\hline Mango & $5.67 \pm 0.018$ & $0.94 \pm 0.012$ & - & $0.30 \pm 0.011$ \\
\hline Cassava & $5.42 \pm 0.015$ & $2.31 \pm 0.010$ & $2.18 \pm 0.007$ & - \\
\hline Oil bean & $6.22 \pm 0.013$ & $0.42 \pm 0.001$ & $1.98 \pm 0.005$ & $0.59 \pm 0.006$ \\
\hline Pear & $10.37 \pm 0.002$ & $1.77 \pm 0.003$ & - & $0.07 \pm 0.015$ \\
\hline \multicolumn{5}{|c|}{ Ohaukwu } \\
\hline Guava & $6.29 \pm 0.007$ & $1.58 \pm 0.002$ & - & $0.84 \pm 0.006$ \\
\hline \multicolumn{5}{|c|}{ Afikpo South } \\
\hline Orange & $2.16 \pm 0.003$ & $0.66 \pm 0.018$ & - & $0.27 \pm 0.011$ \\
\hline \multicolumn{5}{|c|}{ Izzi } \\
\hline Rowam & $3.08 \pm 0.010$ & $0.35 \pm 0.005$ & $1.91 \pm 0.013$ & $0.30 \pm 0.007$ \\
\hline \multicolumn{5}{|c|}{ Ezza North } \\
\hline Cassava & $2.48 \pm 0.002$ & $0.41 \pm 0.001$ & $3.53 \pm 0.005$ & - \\
\hline *SRD 2007 (min.) & 125.00 & 15.00 & 0.50 & - \\
\hline (max.) & - & - & 7.00 & - \\
\hline
\end{tabular}

*Min $=$ minimum, $\max =$ maximum. Source: (Hugland and Expert Group, 2008). 


\section{Conclusion}

Gas emissions levels of $\mathrm{NO}, \mathrm{NO}_{2}, \mathrm{SO}_{2}, \mathrm{CO}$, and $\mathrm{CO}_{2}$ from commonly used domestic fuel wood in Nigeria, as well as the metal concentrations from their ashes, were investigated in this study. The observed gas levels when compared to short term exposure limits indicate environmentally unfriendly nature of commonly used domestic fuel wood and the possible risk of respiratory, pulmonary and carcinogenic diseases that could be associated with their regular usage. This study advocates for less use of fuel wood such as cassava stem and oil bean tree which gave high emission levels of $\mathrm{SO}_{2}$ and $\mathrm{NO}_{2}$. The study also confirms that fuel wood such as gmelina, orange and Indian bamboo burn efficiently with low emission of pollutant gases. The wood ash composition suggests a friendly utilization as soil additive for agricultural purposes depending on the composition of the target soil for application. However, caution is required about persistent ash utilization for a long time which could result to bioaccumulation of these metals in the food chain.

\section{References}

Akande, S., \& Erdtmann, B. (1995). Organic matter and Clay Minerals as Thermal Maturation Indicators in the Benue Trough. In J. Pasava, B. Kribek, \& K. Zak (Eds.), Mineral Deposits: From Their Origin to Their Environmental Impacts, Proceedings of the Third Biennial SGA Meeting (pp. 715-718). Prague/Czech Republic.

Boyd, E., Bruce, N., \& Delgado, H. (2002). Birth Weight and Exposure to Kitchen Wood Smoke during Pregnancy in Guatemala. Environ. Health Perspect. 110(1), 109-114. http://dx.doi.org/10.1289/ehp.02110109

Clark, R. (1992). Marine Pollution (pp. 61-79). Oxford, UK: Cleavendo Press.

Chen, G., Song, G., Jiang, L., Zhang, Y., Zhao, N., Chen, B., \& Kan, H. (2008). Short-term Effects of Ambient Gaseous Pollutants and Particulate Matter on Daily Mortality in Shanghai, China. J. Occupational Health, 50, 41-47. http://dx.doi.org/10.1539/joh.50.41

Diaz, E., Smith-Sivertsen, T., Lie, R. T., Pope, D., Bruce, N., Diaz, A., ... Smith, K. R. (2007). Eye Discomfort, Headache and Back Pain among Mayan Guatemalan Women Taking Part in a Randomized Stove $\begin{array}{llllll}\text { Intervention Trial. J. Epidemiol. Community Health, 61(1), } & \text { 74-79. }\end{array}$ http://dx.doi.org/10.1136/jech.2006.043133

Environment Australia. (2002). Review of Literature on Residential Firewood Use, Wood-Smoke and Air Toxics. $\begin{array}{lllll}\text { Technical Report, } & \text { No. } & 4 . & \text { Retrieved } & \text { from }\end{array}$ http://www.environment.gov.au/atmosphere/airquality/publications/report4/chapter2.html

Enwereji, E. E., \& Ezeama, M. C. (2009). Domestic Energy and the Health Problems of Man and Animals. Middle East Journal of Nursing, 3(2), 57-67.

Guggisberg, M., Hassel, P. A., Michaelchuk, D., \& Ahmad, J. (2003). Respiratory Symptoms and Exposure to Wood Smoke in an Isolated Northern Community. Can. J. Public Health, 94(5), 372-376.

Gundermann, D., \& Hutchinson, T. (1995). Changes in Soil Chemistry 20 Years After the Closure of a Nickel-Copper Smelter Near Sudbury, Ontario, Canada. Journal of Geochemical Exploration, 52(1-2), 231-236. http://dx.doi.org/10.1016/0375-6742(94)00026-8

Huglund and Expert Group. (2008). Guideline for Classification of Ash from Solid Biofuels and Peat Utilized from Recycling and Fertilizing in Forestry and Agriculture. NT Technical Report TR 613 (pp. 1-34.), Nordic Innovation Centre, Stensbergatta 25 NO-0170 Oslo, Norway.

Jayaratne, E. R., \& Verma, T. S. (2001). The Impact of Biomass Burning on the Environmental Aerosol Concentration in Gaborone, Bostwana. Atmospheric Environment, 35(10), 1821-1828. http://dx.doi.org/10.1016/S1352-2310(00)00561-6

Mendham, J., Denney, R. C., Barnes, J. D., \& Thomas, M. (2004). Vogel's Textbook of Quantitative Chemical Analysis (6th ed., pp. 371-383). Delhi: Pearson Education Ltd.

Michigan Department of Licensing and Regulatory Affairs (MDLRA). (1974). Diesel Exhaust Gases (pp. 1-3). Michigan Occupational Safety Health Administration.

Misra, M. K., Ragland, K. W., \& Baker, A. J. (1993). Wood Ash Composition as a Function of Furnace Temperature. Biomass and Bioenergy, 4(2), 103-116. http://dx.doi.org/10.1016/0961-9534(93)90032-Y

Moreira, M. A. C., de Moraes, M. R., Silva, D. G. S. T., Pinheiro, T. F., Vasconcelos Jr, H. M., de Lima Maia, L. F., \& do Couto, D. V. (2008). Comparative Study of Respiratory Symptoms and Lung Function Alterations 
in Patients with Chronic Obstructive Pulmonary Disease Related to the Exposure to Wood and Tobacco Smoke. J. Brasileiro de Pneumologia, 34(9), 300-309.

Najjar, Y. S. H. (2011). Gaseous Pollutants Formation and their Harmful Effects on Health. Innovative Energy Policies, 1, 1-9. http://dx.doi.org/10.4303/iep/E101203

Njiong, A. M., \& Johannes, T. A. (2011). Analysis of Domestic Cooking Energy Choices in Cameroon. European J. Social Sciences, 20(2), 336-348.

Pasquini, M. W. (2006). The Use of Town Refuse Ash in Urban Agriculture around Jos Nigeria: Health and Environmental Risks. Science of the Environment, 354, 43-59.

Pérez-Padilla, J. R., Regalado-Pineda, J., \& Morán-Mendoza, A. O. (1999). The Domestic Inhalation of the Smoke from Firewood and Other Biological Materials. A Risk for the Development of Respiratory Diseases. Gaceta Medica de Mexico, 135(1), 19-29. PMid: 10204309

Pitman, R. (2011). Wood Ash Use in Forestry: A Review of Environmental Impacts. Retrieved from http://www.forestry.gov.uk/pdf/use_of_ash_in_forestry.pdf/\$FILE/use_of_ash_in_forestry.pdf

Riojas-Rodriguez, H., Romano-Riquer, P., Santos-Burgoa, C., \& Smith, K. R. (2001). Household Firewood Use and the Health of Children and Women of Indian Communities in Chiapas, Mexico. Int. J. Occup. Environ. Health, 7(1), 44-53.

Robinson, D. L. (2011). Australian Wood Heaters Currently Increase Global Warming and Health Costs. Atmosphere Pollution Research, 2, 267-274.

Singh, B. (2001). Heavy Metals in Soils: Sources, Chemical Reactions and Forms. In D. Smith, S. Fityus, \& M. Allman (Eds.), Geo Environment: Proceedings of the $2^{\text {nd }}$ Australia and New Zealand Conference on Environmental Geotechnics, Newcastle and New South Wales (pp. 77-93).

Smith, K. R. (2002). Indoor Air Pollution in Developing Countries: Recommendations for Research. Indoor Air, 12(3), 198-207. http://dx.doi.org/10.1034/j.1600-0668.2002.01137.x

Suruchi, \& Pankaj, K. (2011). Assessment of Heavy Metal Contamination in Different Vegetables Grown in and around Urban Areas. Research J. Environment Toxicology, 5(3), 162-179. http://dx.doi.org/10.3923/rjet.2011.162.179

Tanimowo, M. O. (2000). Air Pollution and Respiratory Health in Africa: A Review. East African Medical J., 77(2), 71-75.

\section{Copyrights}

Copyright for this article is retained by the author(s), with first publication rights granted to the journal.

This is an open-access article distributed under the terms and conditions of the Creative Commons Attribution license (http://creativecommons.org/licenses/by/3.0/). 